\title{
PENDIDIKAN KARAKTER SEBAGAI UPAYA MEWUJUDKAN REVOLUSI MENTAL
}

\author{
Muawanah \\ STAB Negeri Sriwijaya \\ umiadhanna@yahoo.co.id
}

\begin{abstract}
Mental revolution starts from the education. Education is very important, as the strategic role of educations is to form children's mental nation. Development of culture and national character is realized through the area of education. Character development education is a continuous process and never ends (never ending process). As long as a nation exist, a character education must be an integral part of education over the generations.

Implementation of character education should not be linked to the budget. It takes commitment and integrity of the stakeholders in the education sector to seriously implement the values of life in every lesson. Character education does not just teach what is right and what is wrong, but also inculcate the habit (habituation) of which one is a good thing. By doing so, students become acquainted (cognitive) about which one is good and bad, able to feel (affective) good value (loving the good/moral feeling), and behavior (moral action), and used to do (psychomotor). Thus, character education is closely related to the habit (custom) practiced and performed.

Children do not need a curriculum, but a real life that support them. They learn from real life. What happens now, a lot of value or an existing teachings that are obscured, covered up with a lie that is packaged in an iconic form of advertising that is actually misleading.
\end{abstract}

Keywords: character, education, mental revolution

\section{Pendahuluan}

Pada dasawarsa terakhir ini, krisis kepercayaan diri bangsa Indonesia sudah cukup memprihatinkan. Berbagai tindakan negatif banyak terjadi di berbagai daerah, mulai dari perilaku seks bebas, tawuran pelajar dan mahasiswa, hingga maraknya kasus bunuh diri. Dunia pendidikan telah memberikan porsi yang sangat besar untuk pengetahuan, tetapi melupakan tujuan utama pendidikan, yaitu mengembangkan pengetahuan, sikap, dan keterampilan secara simultan dan seimbang. Terpuruknya bangsa Indonesia dewasa ini tidak hanya disebabkan oleh krisis ekonomi, melainkan juga oleh krisis akhlak yang berakar dari kurangnya penanaman pendidikan karakter. 
Pendidikan adalah gerbang menuju kehidupan yang lebih baik dengan memperjuangkan hal-hal terkecil hingga hal-hal terbesar yang normalnya akan dilewati oleh setiap manusia. Pendidikan adalah bekal untuk mengejar semua yang ditargetkan oleh seseorang dalam kehidupannya sehingga tanpa pendidikan, maka logikanya semua yang diimpikannya akan menjadi sangat sulit untuk dapat diwujudkan.

Faktanya, memang tidak semua orang yang berpendidikan sukses dalam perjalanan hidupnya, tetapi jika dilakukan perbandingan maka orang yang berpendidikan tetap jauh lebih banyak yang bisa mengecap kesuksesan daripada orang yang tidak pernah mengecap pendidikan, baik pendidikan formal maupun non formal. Pendidikan adalah alat untuk mengembangkan diri, mental, pola pikir dan juga kualitas diri seseorang.

Jika orang yang sudah dibekali ilmu saja terbukti masih ada atau bahkan banyak yang mengalami kegagalan, lalu bagaimana dengan mereka yang tidak dibekali ilmu sama sekali? Logikanya sudah pasti mereka akan lebih kesulitan dalam mengembangkan hal-hal yang diminatinya dengan tujuan untuk mendapatkan level kehidupan yang lebih baik. Proses hidup membutuhkan teori, dan dengan pendidikan lah teori tersebut bisa didapatkan.

Jangan meyakini opini sekelompok orang yang tidak bertanggung jawab. Apa pun alasannya, setiap orang tetap membutuhkan pendidikan. Meskipun pendidikan tidak menjamin kesuksesan seseorang, namun pendidikan akan membekali kualitas diri yang lebih baik sehingga akan lebih berpeluang untuk mendapatkan apa yang dicita-citakan. Pendidikan merupakan alat terpenting untuk merealisasikan semua impian.Pendidikan adalah prioritas untuk menuju ke arah yang lebih baik dan masa depan yang lebih layak.

Oleh karena itu, untuk pendidikan yang lebih baik perlu adanya revolusi mental dalam pendidikan. Dalam bidang pendidikan, revolusi mental harus mampu menanamkan nilai-nilai yang berharga bagi guru, kepala sekolah, dan pengawas, sebagai bekal bagi mereka untuk memberikan layanan yang optimal kepada peserta didik, sehingga mampu melahirkan generasi emas. Mengubah 
mental guru, kepala sekolah, dan pengawas tidak bisa dilakukan secara serta merta dalam tempo yang sesingkat-singkatnya.

Mengingat peran pendidikan sangat strategis dalam membentuk mental anak bangsa. Pengembangan kebudayaan maupun karakter bangsa diwujudkan melalui ranah pendidikan. Pendidikan pengembangan karakter adalah sebuah proses berkelanjutan dan tidak pernah berakhir (never ending process). Selama sebuah bangsa ada dan ingin tetap eksis, pendidikan karakter harus menjadi bagian terpadu dari pendidikan alih generasi.

Sejatinya, pendidikan merupakan sarana pembentuk karakter bangsa. Mengapa? Menurut Kamus Besar Bahasa Indonesia (KBBI), Pendidikan diartikan sebagai proses pengubahan sikap dan tata laku seseorang atau kelompok orang dan usaha mendewasakan manusia melalui upaya pengajaran dan pelatihan. Sedangkan, Karakter artinya cara berpikir dan berperilaku yang menjadi ciri khas tiap individu untuk hidup dan bekerja sama, baik dalam lingkup keluarga, masyarakat, bangsa dan negara. Jadi, pendidikan berkarakter adalah pendidikan nilai, pendidikan budi pekerti, pendidikan moral, pendidikan watak yang bertujuan mengembangkan kemampuan seluruh warga sekolah untuk memberikan keputusan baik-buruk, keteladanan, memelihara apa yang baik dan mewujudkan kebaikan itu dalam kehidupan sehari-hari.

Pembentukan karakter merupakan salah satu tujuan pendidikan nasional. Oleh karena itu, dapat disimpulkan bahwa pendidikan merupakan sarana yang penting dalam pembentukan karakter setiap warga dalam suatu bangsa. Peranan pendidikan akan dapat mempengaruhi kokohnya keimanan dan secara tidak langsung juga moralitas dan karakter bangsa. Fakta historis telah menunjukkan bahwa kemerdekaan bangsa Indonesia dimulai secara nyata dari adanya kecerdasan. Kecerdasan dapat berfungsi setelah disentuh oleh pendidikan dan para penyentuhnya adalah para guru di sekolah. Kecerdasan adalah asset utama untuk melestarikan bangsa itu sendiri. Apapun yang dimiliki oleh suatu bangsa tak akan berarti bila pengelolaannya tidak dilandasi oleh kecerdasan.

Pendidikan karakter pada tingkatan institusi mengarah pada pembentukan budaya sekolah, yaitu nilai-nilai yang melandasi perilaku, tradisi, kebiasaan 
keseharian, dan simbol-simbol yang dipraktikkan oleh semua warga sekolah, dan masyarakat sekitar sekolah. Budaya sekolah merupakan ciri khas, karakter atau watak, dan citra sekolah tersebut di mata masyarakat luas. Sasaran pendidikan karakter adalah seluruh Sekolah yang ada di Indonesia, baik negeri maupun swasta. Semua warga sekolah, meliputi para peserta didik, guru, karyawan administrasi, dan pimpinan sekolah menjadi sasaran program ini. Sekolah-sekolah yang selama ini telah berhasil melaksanakan pendidikan karakter dengan baik dijadikan sebagai best practices, yang menjadi contoh untuk disebarluaskan ke sekolah-sekolah lainnya.

Implementasi pendidikan karakter tidak harus dikaitkan dengan anggaran. Dibutuhkan komitmen dan integritas para pemangku kepentingan di bidang pendidikan untuk secara sungguh-sungguh menerapkan nilai-nilai kehidupan di setiap pembelajaran. Pendidikan karakter tidak sekadar mengajarkan mana yang benar dan mana yang salah, tetapi juga menanamkan kebiasaan (habituation) tentang hal mana yang baik. Dengan begitu, peserta didik menjadi paham (kognitif) tentang mana yang baik dan salah, mampu merasakan (afektif) nilai yang baik (loving the good/moral feeling), dan perilaku yang baik (moral action), dan biasa melakukan (psikomotor). Jadi, pendidikan karakter erat berkaitan dengan habit (kebiasaan) yang dipraktikkan dan dilakukan.

Thomas Lickona, dalam bukunya, Education for Character, menawarkan dua nilai utama pendidikan karakter yang berdasar atas hukum moral, yaitu sikap hormat dan bertanggung jawab. Nilai-nilai tersebut mewakili dasar moralitas utama yang berlaku secara universal. Sebab, itu memiliki tujuan dan merupakan nilai yang nyata bahwa terkandung nilai-nilai baik bagi semua orang, baik secara individu maupun sebagai bagian dari masyarakat.

Ada tiga hal pokok untuk memahami konsep rasa hormat. Pertama, penghormatan terhadap diri sendiri. Maksudnya, mengharuskan kita untuk memperlakukan apa yang ada pada hidup kita sebagai manusia yang memiliki nilai secara alami. Kedua, penghormatan terhadap orang lain, mengharuskan kita untuk memperlakukan semua orang, bahkan orang-orang yang kita benci, sebagai manusia yang memiliki nilai tinggi dan memiliki hak yang sama dengan kita 100 
sebagai individu. Ketiga, hormat terhadap lingkungan, sebuah kewajiban untuk melindungi alam dan lingkungan ketika kita hidup dari rapuhnya ekosistem dan segala kehidupan yang bergantung di dalamnya.

Sedangkan tanggung jawab merupakan suatu bentuk lanjutan dari rasa hormat. Jika menghormati orang lain, itu berarti kita menghargai mereka. Jika menghargai mereka, kita merasakan sebuah ukuran dari rasa tanggung jawab kita untuk menghormati kesejahteraan hidup mereka. Tanggung jawab secara literal "'kemampuan untuk merespons atau menjawab'. Artinya, tanggung jawab berorientasi terhadap orang lain, memberikan bentuk perhatian, dan secara aktif memberikan respons terhadap apa yang mereka inginkan. Tanggung jawab menekankan kepada kewajiban positif untuk saling melindungi.

Sikap hormat dan tanggung jawab adalah dua nilai moral dasar dalam membentuk mental anak yang harus diajarkan di sekolah. Tentunya masih banyak nilai lain, misalnya kejujuran, keadilan, toleransi, kebijaksanaan, disiplin diri, tolong-menolong, peduli terhadap sesama, keberanian, dan sikap demokratis. Namun, nilai-nilai khusus tersebut merupakan bentuk dari rasa hormat dan tanggung jawab atau sebagai media pendukung untuk bersikap hormat dan bertanggung jawab. Bagaimana strategi pengajaran tentang rasa hormat dan tanggung jawab? Bergantung kepada kebijaksanaan masing-masing sekolah.

Pendidikan karakter menjadi sangat penting karena tiga hal: (1) secara makro, telah terjadi kemerosotan karakter bangsa ditandai oleh tingginya indeks korupsi, premanisme dan kekerasan; (2) secara mikro dalam dunia pendidikan juga banyak kasus bullying, tawuran-antar pelajar, kelemahan sistem kurikulum dan proses pembelajaran yang tidak kondusif bagi pembentukan karakter bangsa; (3) Jokowi-JK sebagai presiden dan wakil presiden terpilih sejak kampanye sudah menegaskan perlunya revolusi mental terkait tiga hal utama kedaulatan politik, kemandirian ekonomi dan kepribadian dalam budaya.

Pentingnya pendidikan karakter ini juga seperti kutipan dari Presiden Soekarno bahwa tidak ada pembangunan bangsa tanpa pembangunan karakter bangsa. Mahatma Gandhi juga mengatakan bahwa pendidikan tanpa karakter 
adalah satu dari tujuh "dosa-dosa berat” dari sebuah masyarakat (seven deadly sins of society).

Istilah pendidikan karakter mulai dicetuskan akhir abad ke-18 oleh seorang pakar pendidikan dari Jerman yakni Friedrich Foerster (1869-1966) yang menandai pendidikan karakter dengan 4 ciri yakni: (1) anak didik menghormati nilai dan normatif yang ada, (2) membangun rasa percaya diri sehingga anak didik tidak takut suasana baru, (3) adanya otonomi diri dimana anak didik menghayati dan mengamalkan aturan sampai kemudian terinternalisasi dalam dirinya, dan (4) keteguhan anak dalam mewujudkan apa yang dianggap baik dan penghormatan pada komitmen yang dipilihnya.

Dalam konteks Indonesia, Presiden pertama Soekarno merumuskan UU No. 4/1950 bahwa pendidikan harus sesuai dengan tujuan negara dan perlunya nation and character building karena masyarakat Indonesia mengalami kerusakan mental yang parah akibat penjajahan. Tahun 1965 Soekarno memutuskan Pancasila sebagai dasar Sistim Pendidikan Nasional dan menjadi pelajaran wajib dari Sekolah Dasar sampai Pergurutan Tinggai. Keputusan ini lalu dipertegas Presiden Soeharto di tahun 1967.

Tahun 1976 Pelajaran pancasila di ganti menjadi PMP (Pendidikan Moral Pancasila) dan tahun 1979 Presiden Soeharto menjadikan P-4 (Pedoman Penghayatan dan Pengamalan Pancasila) sebagai program nasional. Tahun 1994 PMP diganti menjadi PPKN (Pendidikan Pancasila dan Kewarganegaraan).

Tahun 2001, di tengah tuntutan reformasi untuk mereformasi Pancasila versi Orde Baru, PPKN di ganti hanya PKN (Pendidikan Kewarganegaraan). Di dunia Pendidikan sejak reformasi Pancasila justru terkesan di pinggirkan. Persepsi peserta didik terhadap pelajaran Pancasila dari SD sampai perguruan tinggi juga sangat tidak menggembirakan.

Sejak terpilih beberapa bulan lalu Jokowi-JK sudah menegaskan perlunya revolusi mental. Di bidang pendidikan, hal ini sinkron dengan Pendidikan Karakter yang belum lama digodok kemendikbud terkait pelaksanaan kurikulum 2013 (K-2013). K-2013 yang relatif pelaksanaannya kacau balau, tapi secara konseptual mengandung menekanan pada aspek tidak hanya kognitif, tapi juga 102 
afektif, motorik dan social-skill sehingga bila dilaksanakan dengan baik dan benar bisa mendorong pembentukan karakter di sekolah.

Pusat Kurikulum Kemendikbud telah menyusun strategi pendidikan karekter ini, yang melalui empat hal yakni pembelajaran (teaching), keteladanan (modelling), penguatan (reinforcing) dan pembiasaan (habituating). Nilai-nilai dalam pendidikan karakter diambil dari empat sumber utama yakni: agama, budaya, Pancasila dan tujuan pendidikan.

Kemendikbud juga telah menetapkan 18 nilai utama dalam pendidikan karakter yakni relijius, jujur, toleransi, disiplin, kerja-keras, mandiri, demokratis, ingin-tahu, semangat-kebangsaan, cinta-tanah-air, menghargai-prestasi, bersahabat/komunikatif, cinta-damai, gemar-membaca, peduli-lingkungan, pedulisosial, dan tanggung-jawab.

Di level sekolah guru akan menjadi ujung tombak pelaksanaan pendidikan karakter karena mereka yang langsung berinteraksi dengan anak didik. Guru sesuai asal katanya di gugu (dipercaya) dan di tiru (menjadi tauladan) memegang peranan penting. Sayangnya profil guru baik dari profesionalitas, kompetensi, kesejahteraan dan pemerataan guru antara kota dan desa masih belum baik. Hal ini harus segera di perbaiki kemendikbud di bawah menteri baru Anies Baswedan.

Selain itu disadari bahwa bagaimanapun pendidikan karakter ini harus dalam koridor revolusi mental. Oleh karena itu, pendidikan karakter akan saling terkait dengan aspek lainnya dalam kehidupan bernegara seperti agama, budaya, sosial, politik dan sebagainya. Oleh karena itu pendidikan karakter di sekolah saja tidak cukup. Porsi yang besar justru dari keluarga dan masyarakat. Pembentukan karakter mensyaratkan sistim politik yang sehat, penegakkan hukum yang adil, kesejahteraan masyarakat yang makin merata dan penghargaan masyarakat atas nilai, norma dan konsititusi yang sudah disepakati bersama.

Istilah "Revolusi Mental" berasal dari dua suku kata, yakni 'revolusi' dan 'mental'. Arti dari 'Revolusi'. adalah sebuah perubahan yang dilakukan dengan cepat dan biasanya menuju kearah lebih baik. Beda dengan evolusi, yang mana perubahannya berlangsung lambat. 'Mental' memiliki arti yang berhubungan dengan watak dan batin manusia. Adapun istilah mentalitas menurut KBBI 
(Kamus Besar Bahasa Indonesia) bermakna aktivitas jiwa, cara berpikir, dan berperasaan. Maka, istilah "Revolusi Mental" dapat ditafsirkan sebagai aktivitas mengubah kualitas manusia kearah yang lebih bermutu dan bermental kuat dalam berbagai aspek dengan jangka waktu yang cepat.

Soekarno, di pidatonya mengatakan ."Dalam kehidupan sehari-hari, praktek revolusi mental adalah menjadi manusia yang berintegritas, mau bekerja keras, dan punya semangat gotong royong." "Revolusi Mental adalah suatu gerakan untuk menggembleng manusia Indonesia agar menjadi manusia baru, yang berhati putih, berkemauan baja, bersemangat elang rajawali, berjiwa api yang menyalanyala.”

Itulah adalah gagasan revolusi mental yang pertama kali dilontarkan oleh Presiden Soekarno pada Peringatan Hari Kemerdekaan 17 Agustus 1956. Soekarno melihat revolusi nasional Indonesia saat itu sedang mandek, padahal tujuan revolusi untuk meraih kemerdekaan Indonesia yang seutuhnya belum tercapai. Kita tahu, negeri ini telah mengalami penjajahan selama 350 tahun. Selama itu pula bangsa kita mendapat penindasan, diperbudak, diperas setiap tetes sumber daya manusia maupun alamnya. Karena itu setelah merdeka, pekerjaan paling besar yang harus dilakukan oleh para pemimpin bangsa adalah membangun mental manusia Indonesia. Caranya, dengan gerakan revolusi mental itu.

Revolusi di jaman kemerdekaan adalah sebuah perjuangan fisik, perang melawan penjajah dan sekutunya, untuk mempertahankan Negara Kesatuan Republik Indonesia. Kini, 70 tahun setelah bangsa kita merdeka, sesungguhnya perjuangan itu belum, dan tak akan pernah berakhir. Kita semua masih harus melakukan revolusi, namun dalam arti yang berbeda. Bukan lagi mengangkat senjata, tapi membangun jiwa bangsa.

Membangun jiwa yang merdeka, mengubah cara pandang, pikiran, sikap, dan perilaku agar berorientasi pada kemajuan dan hal-hal yang modern, sehingga Indonesia menjadi bangsa yang besar dan mampu berkompetisi dengan bangsabangsa lain di dunia.

Kenapa membangun jiwa bangsa yang merdeka itu penting? Membangun jalan, irigasi, pelabuhan, bandara, atau pembangkit energi juga penting. Namun 104 
seperti kata Bung Karno, membangun suatu negara, tak hanya sekadar pembangunan fisik yang sifatnya material, namun sesungguhnya membangun jiwa bangsa. Bahkan masa depan suatu bangsa amat tergantung dengan kemampuan mereka menjaga kebersihan dan kekuatan jiwanya.

Dengan kata lain, modal utama membangun suatu negara, adalah membangun jiwa bangsa. Tentu saja diperlukan keahlian, atau menguasai keilmuan, namun tanpa dilandasi jiwa yang merdeka, pembangunan tidak akan mencapai tujuannya. Inilah ide dasar dari digaungkannya kembali gerakan revolusi mental oleh Presiden Joko Widodo. Jiwa bangsa yang terpenting adalah jiwa merdeka, jiwa kebebasan untuk meraih kemajuan. Jiwa merdeka disebut Presiden Jokowi sebagai positivisme. Sedangkan jiwa budak, jiwa tidak merdeka, atau jiwa yang tidak ingin maju adalah negativisme.

Revolusi mental menurut Presiden Joko Wododo adalah revolusi jiwa bangsa dari jiwa budak yang negativisme ke jiwa merdeka yang penuh dengan keunggulan atau positivisme. Gerakan revolusi mental semakin relevan bagi bangsa Indonesia yang saat ini tengah menghadapi tiga problem pokok bangsa yaitu; merosotnya wibawa negara, merebaknya intoleransi, dan terakhir melemahnya sendi-sendi perekonomian nasional. Lewat gerakan revolusi mental, Presiden Jokowi bertekad membawa Indonesia menjadi bangsa yang berdaulat secara politik, berdiri di kaki sendiri secara ekonomi, dan berkepribadian dalam kebudayaan. Dalam kehidupan sehari-hari, praktek revolusi mental adalah menjadi manusia yang berintegritas, mau bekerja keras, dan punya semangat gotong royong. Pemerintahan Presiden Jokowi berkomitmen untuk jadi pelopor gerakan revolusi mental kepada masyarakat agar menjadi gerakan sosial, karena pelaku revolusi mental adalah seluruh rakyat Indonesia.Para pemimpin dan aparat negara akan jadi pelopor untuk menggerakkan revolusi mental, dimulai dari masing-masing Kementerian/Lembaga (K/L).

Sebagai pelopor gerakan revolusi mental, pemerintah lewat K/L harus melakukan tiga hal utama yaitu: bersinergi, membangun manajemen isu, dan terakhir penguatan kapasitas aparat negara. Setelah pembenahan ke dalam, dilakukan juga pembenahan ke luar lewat edukasi dan keterlibatan 
masyarakat. Gerakan revolusi mental terbukti berdampak positif terhadap kinerja pemerintahan Jokowi. Dalam waktu yang tidak terlalu lama, ada banyak prestasi yang diraih berkat semangat integritas, kerja keras, dan gotong royong dari aparat negara dan juga masyarakat.

\section{Pembahasan}

Revolusi mental merupakan jawaban atas perubahan karakter yang terjadi di tengah bangsa Indonesia. Karakter santun, berbudi pekerti, ramah, dan bergotong royong merupakan karakter orisinal bangsa Indonesia yang belakangan ini mulai hilang dari karakter masyarakat. Perubahan karakter yang merusak mental ini menjadi salah satu penyebab maraknya terjadi korupsi, nepotisme, intoleransi, ketimpangan pembangunan, dan berbagai permasalahan lain di tengah masyarakat.

Revolusi mental adalah upaya untuk mengembalikan bangsa Indonesia kepada karakter aslinya. Namun revolusi ini tidak dapat dilakukan secara sporadik tanpa tujuan dan pendekatan yang tepat. Perubahan mental bangsa yang sudah berlangsung puluhan bahkan ratusan tahun harus diperbaiki lewat revolusi yang terencana, efektif, dan menyentuh semua lapisan masyarakat.

Revolusi mental merupakan upaya untuk mencerdaskan kehidupan bangsa. Maka sesuai amanat Pembukaan Undang-undang 1945, pemerintah sangat berkewajiban menjalankan tugas konstitusional ini. Pemerintah harus dapat merancang skema yang tepat dalam mengupayakan terjadinya revolusi mental. Revolusi mental tidak dapat dilakukan secara sektoral atau per bagian-bagian. Revolusi mental harus dilakukan secara holistik sehingga kembalinya karakter hakiki bangsa Indonesia dapat terjadi secara menyeluruh.

Menjawab itu, pendidikan, baik di tengah keluarga, sekolah, pesantren, organisasi, institusi, dan lain sebagainya, bisa dikatakan adalah satu-satunya jalan untuk bisa mengembalikan bangsa Indonesia kepada karakter hakikinya. Pada hakekatnya, pendidikan adalah usaha membentuk insan-insan akademis yang berpikir mandiri dan dapat bertanggung jawab atas tindakan yang diperbuatnya. Pendidikan sudah dialami manusia sejak berusia muda hingga dewasa. Melalui 
pendidikan diharapkan dapat tercipta kehidupan yang lebih baik bagi diri insan tersebut, juga keluarga, masyarakat, bangsa, dan peradaban manusia.

Undang-undang Republik Indonesia Nomor 20 tahun 2003 tentang Sistem Pendidikan Nasional telah memberikan definisi tentang pendidikan. Menurut UU ini, pendidikan adalah usaha sadar dan terencana untuk mewujudkan suasana belajar dan proses pembelajaran agar peserta didik secara aktif mengembangkan potensi dirinya untuk memiliki kekuatan spiritual keagamaan, pengendalian diri, kepribadian, kecerdasan, akhlak mulia, serta keterampilan yang diperlukan dirinya, masyarakat, bangsa dan negara.

Pendidikan berkualitas akan menghasilkan bangsa berkualitas. Bangsa berkualitas akan menampilkan karakter bangsa yang orisinal dan bermutu. Karakter bangsa yang bermutu ini akan memberantas berbagai keburukan mental seperti korupsi, nepotisme, dan intoleransi. Pembangunan nasional hanya dapat terwujud jika karakter dan pengetahuan masyarakat dikembangkan melalui pendidikan.

Komitmen pemerintah yang kuat disertai kesadaran setiap warga negara akan dapat memampukan mengerjakan revolusi mental. Mencerdaskan kehidupan bangsa adalah tugas bersama. Revolusi mental melalui pendidikan karakter harus terus diupayakan sehingga dapat dibentuk manusia Indonesia yang mampu memanusiakan manusia Indonesia lainnya.

\section{Penutup}

Revolusi mental merupakan bentuk transformasi pembentukan karakter bangsa melalui pembangunan keluarga. Di dalam revolusi mental ditegaskan bahwa karakter dan kesejahteraan bangsa dapat tercipta di awali dari lingkup masyarakat terkecil yaitu keluarga. Keluarga memiliki peran besar dalam proses pembentukan karakter setiap individu yang nantinya merupakan cikal bakal bagian dari bangsa Indonesia. Di sinilah tugas dan peran orang tua mendominasi keberhasilan pembentukan karakter tersebut. Orangtua yang berhasil adalah orangtua yang mampu menciptakan karakter positif yang kuat pada diri anak. 
Revolusi mental diharapkan dapat meningkatkan pemahaman terhadap nilainilai luhur budaya bangsa. Nilai-nilai luhur ini diharapkan menjadi karakter yang menjadi landasan untuk memperkuat kebersamaan dan persatuan, toleransi, tenggang rasa, gotong royong, etos kerja dan menciptakan kehidupan keluarga yang harmonis.

Keluarga memegang peranan penting dalam membangun perubahan mental yang dibutuhkan oleh Indonesia melalui 8 (delapan) fungsinya yang dimilikinya yaitu fungsi agama, pendidikan, cinta kasih, perlindungan, reproduksi, social dan budaya, ekonomi, dan lingkungan. Peran inilah sebagai upaya implementasi gerakan revolusi mental. Lantas apa yang diharapkan dari pendidikan zaman ini? Dunia berkembang sangat kompleks. Teknologi menjadi pemacu utama yang membuat orang kaget setiap waktu. Situasi dan suasana yang serba baru selalu bermunculan setiap saat. Maka pengaruh kemajuan teknologi membuat manusia kewalahan dalam mempertahaankan hal-hal yang baik. Dalam situasi demikian, kemajuan zaman yang begitu cepat menantang sekaligus menuntut tanggung jawab atas dunia pendidikan kita. Tantangan kemajuan zaman akhirnya menghadirkan sikap mental instant dan jalan pintas untuk mencapai kualitas atau kesuksesan tanpa proses. Prinsip klasik: ”berjuang sekuat tenaga dulu baru dapatkan hasil yang baik” gugur. Orang harap gampang tanpa proses, serba instant itu yang bertumbuh subur, wajah pendidikan makin suram. Maka yang menjadi harapan kita adalah penataan dunia pendidikan yang lebih baik karena dunia pendidikanlah yang menjadi oven pemanusiaan manusia. Tugas dan tanggung jawab lembaga-lembaga pendidikan adalah janganlah mereduksi misi pemanusiaan manusia hanya sebatas penataan intelek/otak saja, tetapi perlu pendidikan budi pekerti, pembentukan mental, pembinaan iman serta pendidikan watak yang sejalan sehingga out put dari dunia pendidikan tetap menghasilkan insan-insan pecinta kebenaran yang berkepribadian utuh tanpa pincang. Revolusi mental adalah solusi yang terbaik untuk Indonesia. 


\section{Daftar Pustaka}

Fizha, Fit. 2015. Revolusi Mental Membangun Jiwa Merdeka Menuju Bangsa Besar. Kominfo.go.id. Diakses tanggal 31 Desember 2015

Koesoema, Doni. 2015. Pendidik Karakter di Zaman Keblinger. Jakarta: PT. Gramedia Widiasarana Indonesia.

Mulyasa. 2015. Revolusi Mental Dalam Pendidikan. Bandung: PT. Remaja Rosdakarya.

Muslich, Masnur. 2014. Pendidikan Karakter Menjawab Tantangan Krisis Multidimensional. Jakarta: Bumi Aksara.

Sinarat, Sahat Martin. 2015. Revolusi Mental dan Upaya Mencerdaskan Kehidupan Bangsa. Satuharapan.com. Diakses tanggal 31 Desember 2015.

Suprapto, B. 2014. “Revolusi Mental di Mulai dari Pendidikan”. Jawa Pos. 05 September 2014. 